\title{
Homo Sacer: Ahmadiyya and Its Minority Citizenship (A Case Study of Ahmadiyya Community in Tasikmalaya)
}

\author{
Ach. Fatayillah Mursyidi1 ${ }^{*}$, Zainal Abidin Bagir ${ }^{2}$, Samsul Maarif ${ }^{3}$ \\ Universitas Gadjah Mada, Yogyakarta, Indonesia; e-mail: ach.fatayillah@mail.ugm.ac.id \\ 2 Universitas Gadjah Mada, Yogyakarta, Indonesia; e-mail: zainalbagir@ugm.ac.id \\ 3 Universitas Gadjah Mada, Yogyakarta, Indonesia; e-mail: samsul.maarif75@ugm.ac.id \\ * Correspondence
}

Received: 2020-08-27; Accepted: 2020-11-30; Published: 2020-12-30

\begin{abstract}
Citizenship is among the notions mostly contested after the collapse of a long-standing authoritarian regime in 1998. The reform era - after 1998 - radically transformed Indonesia into a democratic country and brought many other issues including minority issues into the forefront. Unlike other countries that draw their citizenship on a clear formula between religious and secular paradigm, Indonesia, due to ambivalence of its religion-state relation, exhibits fuzzy color of citizenship that leaves space for majority domination over the minority. In consequence, the status of Ahmadiyya for instance, as one of an Islamic minority group, is publicly questioned both politically and theologically. Capitalized by two Indonesian prominent scholars, Burhani (2014) and Sudibyo (2019), I conducted approximately one-month field research in Tasikmalaya and found that what has been experienced by Ahmadiyya resembles Homo Sacer in a sense that while recognised legally through constitutional laws, those who violate their rights are immune to legal charges. This leads to nothing but emboldening the latter to persistently minoritise the former in any possible ways.
\end{abstract}

Keywords: Ahmadiyya; Citizenship; Homo Sacer; Minority; Tasikmalaya.

Abstrak: Kewarganegaraan termasuk di antara istilah yang kerap diperdebatkan pasca peristiwa runtuhnya rezim otoriter yang lama berkuasa pada tahun 1998. Era reformasi - pasca 1998 - secara radikal mentransformasi Indonesia menjadi negara yang demokratis sekaligus membangkitkan isuisu lain termasuk isu minoritas. Berbeda dengan negara-negara lain yang mendasarkan konsep kewarganegaraan mereka pada formula yang jelas antara paradigma agama atau sekuler, Indonesia, mengingat ambivalensi relasi agama-negara, memiliki warna kewarganageraan yang samar sehingga memberikan ruang pada dominasi mayoritas atas minoritas. Akibatnya, status Ahmadiyyah misalnya, sebagai salah satu kelompok Islam minoritas, secara umum dipertanyakan baik secara politik maupun teologis. Berbekal teori dari dua kesarjanaan ternama Indonesia, Burhani (2014) dan Sudibyo (2019), saya melakukan sekitar satu bulan penelitian lapangan di Tasikmalaya dan menemukan bahwa apa yang dialami oleh jamaat Ahmadiyah menyerupai Homo Sacer-nya Agamben dalam arti bahwa meskipun diakui secara hukum melalui Undang-Undang, mereka yang melanggar hak-haknya kebal dari sangsi hukum. Hal ini hanya akan mengakibatkan mayoritas terus melakukan upaya minoritisasi terhadap kaum minoritas.

Kata Kunci: Ahmadiyah; Homo Sacer; kewarganegaraan; minoritas; Tasikmalaya.

\section{Introduction}

Unlike most European countries that draw their citizenship formula on a liberal and secular paradigm, Indonesia bears a fully distinct conception of nationhood. A closer look at the set of its constitution, we will be perplexed of determining the color of its citizenship due to of grey zone of the 
relationship between religion and state. This equivocality has attracted many international scholars to visit Indonesia, either physically or intellectually, to grant their attempts to understand the type of relationship displayed by both religion and state within the country. Many terms have been given all of which do not cover the very idea of the relationship comprehensively. Godly nationalism is one of the notions offered by Jeremey Menchik. After twenty-four months of field research in Indonesia, he comes to find the term defined as "an imagined community bound by a common, orthodox theism and mobilised through the state in cooperation with religious organizations in society" (Menchik, 2016, p. 72). In the context of Indonesia as a Muslim majority country, those civil organizations are mostly represented by Nahdhatul Ulama (NU) and Muhammadiyah as the two largest Islamic organizations. Rather than being trapped into two main models of state-religion relation, secularism, and theocracy, he represents a new model for Indonesia seen in the goal of those two major organization. In this case, he sees religious values and education, particularly belief in God, incorporated into social and political life.

The ambivalence of religion-state relation yielded a vague shape of Indonesian citizenship by which social, as well as political costs, were also brought about. Historically speaking, it may be dated back to the early formation of the Indonesian state at the time of which two groups appeared; religious and nationalist blocks. Many considerable pieces of works of literature have been given to portray the fierce debate between those two ideological blocks in terms of determining a foundational basis for the infant Indonesia (Elson, 2009; Ismail, 2004; Latif, 2011). The first group is represented by Islamist scholars who advocated for religious basis under Islamic law while the second symbolised by Soekarno himself argued for more secular and theologically neutral notion under nationalist ideology, which later called Pancasila.

Despite the remnant of Islamist visions, the debate was eventually triumphed by the nationalist group and brought Pancasila up to the official reign of Indonesian ideology. Interestingly, this victory did not necessarily leave religious ideas behind as they are, to some degree, still taken into very account in Indonesian politics. This is where exactly religion plays its part in subsequent political discourses since its values are matters very much throughout the historical journey of Indonesian politics. Ahyar (2015) described this fact as an ideological tension between religious and secular nationalism that gave away to Menchik's godly nationalism.

The partial involvement of religious affairs in the public sphere helped to accelerate the initial construction of colorless citizenship of Indonesia. Far from what has been commonly understood in liberal understanding, this particular type of citizenship prioritises community over individuals (Menchik, 2016), harmony over protest (Berenschot \& Van Klinken, 2018), and evolving-informal over static-formal relations (Guillaume, 2014). It mounted in particular following the collapse of the New Order regime since the time of which the political crane is freely opened, resulting in a wide range of civic participation for even those who used to stand for religious ideas. What is unfortunate is that the type of aspiring the ideas that are rather through informal-political than formal-legal connections.

One of the consequent results of this kind of citizenship is what Klinken and Berenschot called a gap between law-on-paper and law-in-practice (Klinken \& Berenschot, 2018, p. 154). This is seriously due to the implementation of the law that does not depend on the principle of equality before the law but on who has a closer relationship to those in charge. In this sense, the minority is the most vulnerable community of not finding sufficient access to claim their civil rights though they have been guaranteed by the written law. The lack of number might reduce their significance in the view of politicians in power, as the latter will likely refuse any attempt of building informal relations by the former.

The majority, in contrast, benefitted very much from the display of this citizenship for they have something in return to strengthen their bargaining power. They have a large number that can be transferred into a huge vote. Under this advantageous circumstance, they exercise a better chance of protecting rights, in any case, they may cope with rather those who are in minority. The case of Ahmadiyya is only one among many other issues affected by this minority-majority impartial relationship that derived from the improper way of how the notion of citizenship is conceptualised in Indonesia. Along with other religious minority groups, such as Shi'ite and other non-Islamic religions, 
Ahmadiyya is most burdened by this informal type of citizenship. This is, in part and foremost, due to its liminal status in religious and political territory that will be discussed throughout this paper.

In a practical situation, it is well evidenced by a series of violent attacks against the community afterward that reach its peak at both the case of Cianjur and Tasikmalaya, two regions in West Java with a high frequency of violence against Ahmadiyya (Mudzakkir, 2011, p. 12). Unlike Cianjur, Ahmadiyya in the latter region is quite uniquely more appealing as the violent actors come not only from the state of common society represented by radical mass organizations but also from state apparatus and ex-Ahmadis themselves. It is appealing for the latter did not only drop their faith down but also turned to attack their former belief. These specific actors are assembled under an organization, namely the Civil Association of Victims of the Ahmadiyya Heretical Sect (IMKASA). There was even a report that the destruction of the Ahmadis mosque in 2003 in Tasikmalaya was triggered by a provocative speech by Ahmad Hariadi, an ex-Ahmadis muballigh (preacher), who degraded the Ahmadis teachings few days before the attack (Mudzakkir, 2017, p. 67).

Ahmadiyah was brought to Tasikmalaya by Entoy Muhammad Toyyib. He had been assigned by M. In late 1934, Rahmat Ali promoted Ahmadiyah to areas like Bandung, Sumedang, Cianjur, Garut, Tasikmalaya and Ciamis in Priangan. Entoy was very active in his fight to support Ahmadiyah. It can be seen from the fact that the first organization of Ahmadiyah was in Tasikmalaya on May 1, 1941 (Nurdin, Jamaludin, Supriatna, \& Kustana, 2019; Sofianto, 2011). He also expanded his promotion of Ahmadiyah to several Tasikmalaya sub-districts, such as Singaparna, Salawu, Sukaraja, and Sukaratu. Ahmadiyah grew very well from these four areas in the sub-districts of Singaparna and Salawu. The village of Cipakat became the central base of Ahmadiyah in Singaparna, while it was centralized at Tenjowaringin village in Salawu. The Ahmadiyah's movement in the area could not be diminished, according to an official informant from the Ministry of Religious Affairs of Tasikmalaya. Ahmadiyah has been part of the Islamic community's historic growth in Tasikmalaya (Usep Saepudin Muhtar, Personal Communication, June 28, 2018).

By conducting approximately one-month field research in Tasikmalaya, this paper aims to underpin the given argument by looking in particular at the case of Ahmadiyya in that region in which their legal status is questioned all the time; they do not belong to both Muslim and non-Muslim respectively. Notice that Ahmadiyya in this case refers only to its Qadiyani branch for I found in Lahore in the field. They are rejected by the majority of society where they live and being labeled as nonMuslim as their teaching is allegedly containing deviant elements that lead them away from the Islamic corridor, while they persistently declare themselves as part of Islam that is, even more, the true part of Islam. In consequence, as they are trapped in a non-align identity, their civil rights are postponed and its deprivers are left immune.

\section{Ahmadiyya and its 'Controversial' Teachings}

Apart from their fervent endeavor of convincing Indonesian mainstream Muslims for their 'Islamity,' there are some Muslims, who are not minor in number, attempting to exclude them from Islamic religion for they allegedly bring several alien teaching unrecognised and condemned by the 'real Islam.' Accordingly, Ahmadiyya is considered a deviation from the 'true Islam' in its five doctrines from which controversy is consequently raised; the concept of prophecy, holly book, caliph, jihad, and crucifixion of Isa or Jesus.

In the first doctrine, they hold a different interpretation on a particular verse in Al-Qur'an discussing the final prophecy of Muhammad. They do not share a common belief with other Muslims in general that Muhammad is the last and seal of the prophet. Instead, they believe that prophecy will remain to continue as far as human history still goes on. This led to a fundamental acknowledgment that their founder, Mirza Ghulam Ahmad, is a prophet of today's era whose teaching is none other than what has been brought by Prophet Muhammad in the early history of Islam. In their word, Ahmad is captured as a zhili prophet, by zhili means a shadow or silhouette (Budiwanti, 2009, p. 4; Valentine, 2014, p. 102)). As such, they deny having brought new teaching such as accused by their opponents. 
The second doctrine is what has been widely misunderstood by civil Muslims at the grassroots concerning the holy book of the community. It is largely taken for granted among them the fake issue that tadzkirah, not Al-Qur'an, as their sacred book. This prejudice has been clarified by the Ahmadis many times and in many opportunities. They argue that the book is a Good News that is revealed by God to Ghulam Ahmad through kasyaf (transcendental experience usually obtained while dreaming). It is consisting of a compilation of his notes collected and codified by the second caliph, Mirza Bashiruddin Mahmood Ahmad, to give their followers spiritual lessons (Budiwanti, 2009, p. 11).

Wherever this divisive issue comes from and whoever in charge of disseminating it in its inception is no longer an important subject compared to the social impacts it brings. It has created a religious prejudice against the community arguing that it reveals and propagates a new religious dogma grounded in their false holly book, went further to the extent that gave a space for ceaseless violent acts perpetrated by their opponents. Apart from other teachings, this particular subject, along with the prejudice of replacing Mecca with Qadiyan as a place for the religious pilgrimage (Mariani, 2013, p. 12), is the most susceptible to a priori accusations delivered by their opponents.

The idea of Khilafah as their third most contended doctrine is no less controversial. The notion of khilafah in its common sense has already been fiercely rejected and anticipated throughout Indonesian history. The gloomy experiences with religious radicalism and separatism have conferred Indonesia a sense of trauma in dealing with organizations aspiring for the ideology. Therefore, in its very category, it was opposed to Pancasila as the foundation of Indonesia. However, tension against this idea is currently re-appeared since those who dreamed to see an Islamic State in this country actively promote it again. However, it is very worth underlining the pivotal difference between the first and second ideas of khilafah for they are promulgated by a very different community. Though both communities emphasize the imperative necessity of implementing the idea, they differ in what sector and how it should be.

Unlike the second concept, khilafah according to Ahmadiyya, is not designed to change and replace any existing political system in a state where they live. In a book review and discussion held in Sunan Kalijaga State Islamic University on May 27, 2019, Ulil Abshar Abdalla, one of the liberal Indonesian Muslim intellectual who is invited as a speaker, argued that the idea of khilafah adopted by Ahmadiyya is a non-politic, one that is also adopted by many Sunnis. It is affirmed by Abdul Rozzaq, another speaker from Ahmadiyya, who insisted that the idea aims to disseminate peace among human kinds rather than fear let alone terror. In sum, the concept bears rather spiritual than political meanings, by which it is essentially aimed to unite Muslims all across global territories, no matter what system the state in which they stay adopts, transcendentally.

The next controversial concept is concerning the idea of jihad that found its more benign meaning in Ahmadiyya literature. For mainstream Muslims, jihad was given a physical meaning that is identical to war against the non-Muslim community. Despite a large debate on how and when it should be conducted and the criteria of the target against whom it must be waged, most of them are in consent of embedding it a sense of physical war. Reversing the idea quite radically, Ahmadis believe that the concept has rather more something to do with literature than literally meaning. In their sense, the latter seemed contradictive with the teaching of Islam that is rahmatan lil alaamin (blessing for all creatures) by bringing peace for everyone with no exemption.

This way they understand the concept reflected also in the way they respond to the British colony at the time by which they must consequently bear a label of British puppet. As they replace jihad bil saif (jihad using the sword) with jihad bil qalam (jihad using the pen), they insisted that the colony must be driven out of India with words, not blood. According to them, the ink of scholars is holier than the sword of martyrs (Budiwanti, 2009, p. 12). As quoted by Erni Budiwanti (2009, p. 12), their fourth caliph used to say that "swords can win territories but not hearts, a force can be claimed, but not minds." This soft approach in countering colonialism was rewarded by a series of stigma condemning their nonaggressive attitude as if it signed their sidedness with British colony.

The last is their understanding of the history of the crucifixion of Isa. In this regard, they even went broader contesting the two common narratives all at once commonly accepted by two world religious 
traditions, Islam and Christianity. Neither they believe that Isa has been crucified until die on the cross as Christians do, nor that he has physically ascended to heaven as mainstream Muslims do. Instead, they built their own history suggesting that Isa has though been crucified but he survived and traveled to Kashmir in which he eventually spent his life (Budiwanti, 2009, p. 5). It is evident from the discovery of his tomb in the northern region of the Indian subcontinent that strengthens their argument. Here is where they dig their liminal status between Muslim and non-Muslim on which I will discuss more later.

Considering those theological differences, they are, on one side, enforced to declare their religion fully separated from Islam as embraced by most Indonesian population. As soon as this argument is proposed, another question appears, on the other side, there are only six religions officially recognized by the Indonesian government. Therefore, the further question is that can their existence be well accepted by merely following the argument. It turns out that by establishing a new religion they position themselves out of Indonesian citizenry unless the state adds the community into the list of 'official religions.' In this situation, they are best portrayed in the next section as a community that is forced to residing a liminal status in a religious democratic country.

\section{Ahmadiyya as Homo Sacer: Recognised but Not Protected}

Up to this point, the Ahmadiyya community places a dilemmatic position, pushing them further into space where their right to exist is legally legitimised by referring to 1953 law while those who deprive their rights are immune from punishment. This sense of immunity affirms allegedly notorious dissidents of the community in a significant way through which unjustified violence against them is relentlessly reproduced. In this regard, Najib Burhani (2014) and Agus Sudibyo (2019), two prominent Indonesian scholars, discerned a categorical similarity between the community and what Agamben (1998) called Homo Sacer in his book, Homo sacer: Sovereign Power and Bare Life.

By referring to Pompeius Festus in his treatise, On the Significance of Words, who combined a figure of archaic Roman law in which the notion of sacredness is devoted simply to human life and a definition of Sacred Mount consecrated to Jove by plebeians during their secession, Agamben (1998, p. 71) understood the category of Homo Sacer as follows:

At homo sacer is est, quern populous iudicavit ob maleficium; neque fas est eum immolari, sed qui occidit, parricidi non damnatur; nam lege tribunicia prima cavetur "si quis eum, qui eo plebei scito sacer sit, occiderit, parricidia. Ne sit." Ex quo quivis homo malus atque improbus sacer appellari solet.

(The sacred man is the one whom the people have judged on account of a crime. It is not permitted to sacrifice this man, yet he who kills him will not be condemned for homicide; in the first tribunal law, in fact, it is noted that "if someone kills the one who is sacred according to the plebiscite, it will not be considered a homicide." This is why it is customary for a bad or impure man to be called sacred).

The definition, Agamben confessed, is far from being seen as unproblematic considering several modern scholars who critically problematise the very definition particularly in the attempt of understanding two contradictive stretches, neque fas est eum immolari, sed qui occidit, parricidi non damnatur (it is not permitted to sacrifice this man, yet he who kills him will not be condemned for a homicide). These sentences are in contradiction in the sense that one should not be murdered according to religious prescripts while those who do that are immune to legal consequences.

As far as related to the sacred actor, according to Agamben, the scholars are divided into two positions of interpretation: those who see sacratio (consecration) as a secularised remained mode of archaic phase in which religious and royal laws were not to be separated and, consequently, the death sentence was understood as a sacrifice to gods and those who see the idea to have substantial aspects of sacredness that both attract veneration and provoke horror. For this last group, the idea is comparable to the notion of taboo that is either adored or condemned.

With that different understanding of the notion of sacratio, both hold partial acceptance about the aforementioned two contradictive stretches. For the first bunch, the last stretch, sed qui occidit, parricidi non damnatur, is understood by simply looking at the status of the death sentence executor for instance. 
However, they remain being stuck in understanding the ban on sacrifice for as long as it was understood as a spiritual offering to their gods. Meanwhile, for the second group, what is understandable is the former stretch instead, neque fas est eum immolari, for sacer is understood as being already possessed by gods thereupon putting them into death is no longer necessary. Therefore, it is out of their sense to see anyone who kills the homo sacer without being condemned for committing sacrilege.

Homo Sacer, according to Festus, overcomes this contradiction by suggesting itself as its political product in which those two characters are rather logical consequences than merely categorically possible (Fowler, 1911). It is in this kind of human where both criteria can be going along without tension at least in its practices. While they are not allowed to be sacrificed in the name of any kind of doctrinal pretexts, those who commit violence or even murder against them are not to be charged for killing sacred life.

Nevertheless, what defines the status of homo sacer, according to Agamben (1998), is not this ambiguous character of sacredness but rather the consequence it brought about concerning a double exclusion they experienced. Here, we arrived at the second key term of Agamben's theory that is 'barelife.' This is a life of a sacred man, in Roman understanding, which placed a liminal space in between two political, legal, or religious categories. In Roman works of literature, these categories were represented by royal order (ius humanum) and religious order (ius divinum) from both of which the sacred man are excluded; they are simply set outside human jurisdiction without being invoked to the religious one. Thus, where were they? In a bare life.

The liminal position carries with it further impacts on their political or even existential status. On one hand, the ban on immolation is due to their exclusion from any religious category to which they do not deserve. Here, again, the ambivalence of the term 'sacred' appeared in a way that distinguishes between sacred things and sacred man, between homo sacer and consecrated sites. "While it is forbidden to violate the other sacred things, it is licit to kill the sacred man (Cum cetera sacra violari nefas sit, hominem sacrum ius fuerit occidi)." While on the other hand, the impunity in killing them is the following consequence of their exclusion from human juridical system by which their political identity is relentlessly questionable.

The following discussion will see the reasons both Burhani (2014) and Sudibyo (2019) in their respective works argued for similarising homo sacer with Ahmadiyya in Indonesia by its liminal trait of bare-life after which some critical notes will be covered in the last section.

\section{Burhani and Sudibyo: Aspects of Liminality and Human Rights Paradox}

According to Burhani (2014, p. 145), the adoption of the concept in the study of Ahmadiyya in Indonesia relevantly matches in four aspects. The first aspect lies in the ambiguity of the notion of 'sacred' in homo sacer, on the one hand, and the position of Ghulam Ahmad as well as the concept of 'halal' in the discussion of Ahmadiyya, on the other. The prophetic status of Ghulam Ahmad, as discussed earlier, is one of the most controversial teachings of the community, leading to a harsh condemnation against the figure among hardliners. Believed as a sacred figure, prophet, promised Messiah, or reformer (in Lahore branch) by his followers, he is accused as a deceiver, blasphemer, and false prophet. This accusation invited illegitimacy from the point of view of hardliners on the religious status of the charismatic figure and finally on the divine revelation he used to receive.

This ambiguity is also applied to the concept of halal that is associated with two contradictory meanings. First, it can be positive when it is used to identify the kind of foods allowed to consume while those that are prohibited such as those not-slaughtered dead animals, blood, pork, and on are categorically identified as haram (forbidden to be eaten as mention in the Qur'an Chapter of Al-Maidah Verse 3). However, second, it may turn out to be negative as long as it is attached to one's life and soul by which means that they are allowed to be killed. Ahmadiyya and Shia are two Islamic streams regularly targeted through this kind of attack by denouncing their blood as halal for they have been accused of manipulating Islamic teachings. 
The second aspect is related to the liminal status of the Ahmadiyya, as they can be seen as neither Muslim nor non-Muslim. The ambiguity settles in how the community is perceived by those who are convinced by its sanctity and those who are disgusted by its teachings. The former insisted that what they have is an origin of Islamic teaching revealed in the Qur'an to which all who call themselves Muslim should refer, in the sense of which it confers them a sense of missionary as other Islamic sects. Meanwhile, the latter sees many deviant teachings incompatible with what they understand about Islam. Rather than believed to have been spoken by God himself, the latter accuse it like a demon's voice.

The third aspect deals with the corollary of its liminal status. As they are unwilling to announce their religion, their rights as Muslims are deprived while, at the same time, their rights as non-Muslims are suspended until they admit that they are not Muslim. Despite state's equal treatment, at least ideally, over existing religions, notice that the country listed only six religions in its administration, excluding, at least until recently, even local beliefs who have been existed far before the formers come and rule. Having no alternative other than being accepted as an Islamic sect with legal rights, it affirms its liminality and similarity with homo sacer in concept.

Finally, in the last aspect, Burhani refers to a series of persecution, violence, and abjection of this group as a logical consequence of that ambiguity and their 'bare life' existence. Carrying this liminal position, they experienced those raw deals more than other communities did. Ironically, that violence is grounded on Indonesian controversial laws, including multi-interpretation law No.1/PNPS/1965 on defamation of religion to which a joint ministerial decree in 2008 that comprises of provocative provisions referred.

Those discriminative and violent acts are, according to Sudibyo through his personal opinion as an expert witness conveyed in a judicial review concerning UU No.1/PNPS/1965 on defamation of religion re-brought to the court by 9 Indonesian Ahmadis (Sudibyo, 2019), problematic in the context of a democratic country such as Indonesia that renders on the law supremacy. Following Agamben's thesis statements in his considerable works, Sudibyo started first of all by pointing out the paradox within the institutionalisation of human rights that, accordingly, is very abstract in its premises and problematic in its implementation. In the context of nation-state, in which Agamben problematised the way the notion of citizenship is conceptualised, the citizen does not refer to an individual who is independent and autonomous in his/her self, but rather, to a member of a certain community with a very strong sense of commonality and collectivity. One is always rather understood as part of communal society forming nation identity than a subject who is endowed with inherent freedom. In this view, community preceded individuality (Menchik, 2016).

In practice, primordial identities are, in fact, still widely used to constitute a citizen. Someone cannot immediately be acknowledged as a citizen only by observing his/her nationality or considering him/her as a human but tracking back also one's race, religion, or/and custom. In this regard, partiality in identity is searched to the very basis in contrast with universal and impartial humanitarian values. These racial considerations are reflected in many existing laws and policies about minority people vis a vis majority. Indonesia is far from being an exception.

This conceptual fact is leading to what later Agamben called people in bare-life; those who live without rights and law protection. From here, Sudibyo, helped by Agamben's analysis, comes to the next paradox of human rights. The state exercises the politics of both inclusion and exclusion respectively; it absorbs civil elements largely into an order in which regulations are implemented and at the same time leaves them alone by suspending law protection when it is needed. Those minority people in bare life are included in a sense that as a part of the national community they should abide by prevailing law, pay tax, obey governmental policies, and reply police or court call, and excluded as their obedience is not rewarded with legal security, let alone rights fulfillment.

In the context of the legal country, and here is the next paradox dwells in, they are not allowed to retaliate to those who deny their rights by attacking them violently. In heartless words, they are omitted with no legal equipment to cope with that violence by themselves after what they have given fullheartedly for the respective state. Recalling Agamben's radical idea, the nature of political relation 
between law (state) and life (citizen) is rather an abandonment than an application (Agamben, 1998). It holds life within a legal order and abandons it to be 'freely' either included or excluded. This thesis meets its practice completely in the case of Ahmadiyya, Shi'ite, indigenous, and sometimes other recognised religions in Indonesia most considerable of which is Confucianism.

\section{Fundamentalism in Democracy: Tracking the Perpetrators}

The secular system, as some may call it, does not necessarily offer a democratic space in which all civil elements can freely participate, and those who oppose it may be automatically eliminated. In fact, here is, in its very definition, the problem lays on. Democracy prerequisites diversity. A homogenous society by itself cannot produce a democratic institution as it has no diverse voices to offer. As such, to fulfill its definitional condition, the system should welcome all political worldviews including those who dislike and condemn its implementation. These opponents are not excluding religious fundamentalism who are fighting for its replacement with religious ideology and system.

Looking at another puzzling pattern, democracy, as an electoral method of election, needs a categorical boundary between who is supposed to be a citizen entitled to the right to vote and who is not. A sovereign country does not accept any legitimacy from unknown people with no political identity. Therefore, political criteria are needed to determine who ins and outs are. However, this notion is also troubled by a further question; who is in charge of determining a nation? Finally, there is still a gap in democracy.

By harnessing this lacuna, religious fundamentalism, again, comes in. They build their criteria based on their religious perspectives. This is problematic since religion contains absolute ideas that can put diversity in jeopardy. Secularisation, which is commonly understood as a total separation between state and religion, is born through this consideration. It can now help us to understand a common tendency in political science of associating this process with the idea of democracy that we discussed earlier. However, again, even the movement should not be isolated from the political process as long as democratic values are held.

In the context of this research, the fundamentalist movements considered as excluders are represented by those who reject the existence or postpone the rights of the Ahmadiyya community. In the academic treasury, they are given with various names in many works of literature discussing the minorities, ranging from Islamist (As' ad, 2009; Ropi, 2010), hardliner, radicals (As' ad, 2009; Mariani, 2013; Mudzakkir, 2011), conservatives (Connley, 2016), and the likes.

\section{Government Institutions}

As it has been explored earlier, Indonesia differs itself from other secular countries in the sense that it does not submit totally to secular ideas. The establishment of The Ministry of Religious Affairs is among other things to imply the involvement of religious elements within Indonesian daily life. It was established in 1946 in the lack of definition and conceptualisation of Ketuhanan yang Maha Esa (Believe in the supreme God), the first principle of Indonesian philosophy, Pancasila, another indication of the religious country. Having been taken been into account both structurally and philosophically, religious values, particularly Islam in this case, become part of national identity that crucially helps to determine legal products, its produced, and the color of its citizenship to whom the products are implemented.

Unfortunately, its establishment was not born out of a neutral political environment since the moment it took place was a critical juncture for the nation's future in which two parties, Muslims and nationalists, were in a debate of formulating the shape of the nation; while Muslims proposed an Islamic state, nationalist preferred a secular one. The Ministry was deliberately founded to accommodate the first group after their defeat a year earlier. However, it seems loose to go further by being a bastion for their conservative ideas, which we find justifiable by looking at its track records (Ropi, 2017, p. 2). To mention some of them are its compliance with MUI's statement against Ahmadiyya in 1984 (Budiwanti, 2009, p. 14) and official sign on a Joint Ministerial Decree in 2008 along with the Ministry of Home Affairs and the Attorney General (Hasyim, 2011, p. 22). 
In the context of Tasikmalaya, a local-based government institution under this Ministry that plays an important role as one of those excluders in minoritising and creating a liminal state for Ahmadiyya community is Religious Affairs Office (KUA). This Office was formed to carry out some of the duties of the Ministry in a sub-district context one of which is to register a marriage by a local Muslim civilian couple. A marriage that is not registered through this office, even though it was run following Islamic legal procedures, remains constitutionally unlawful and potential of being problematised for not securing a marriage book. In Islam adopted by Indonesian terminology, this is known as nikah sirri (secret marriage) that is religiously but not officially valid. The case of Ahmadiyya in Tasikmalaya will show us in the next chapter the way the office, inspired by its main institutional characters, perform this particular task in a very discriminative way.

\section{Civil Society Organizations}

\section{The Council of Indonesian Ulama (MUI)}

In the New Order era, all civil elements are coordinated under a governmental regime through its heavy-handed approach to anticipate a sense of rebellion and social uprising. Its political goal at the time, which is national development, leads to a disregard of cultural as well as religious diversity. MUI was born within this political situation. This regime, under its Minister of Religious Affairs, Mohammad Dahlan, funded the Centre for Islamic Propagation (Pusat Dakwah Islam) to organize an Islamic conference on 30 September -4 October 1970. Of the results, one is a final recommendation regarding the importance of establishing a council of national ulama (Majelis Ulama Nasional). Fulfilling the recommendation, MUI was officially established on 26 July 1975 (Hasyim, 2011, p. 4).

Several pieces of literature provided factors underpinning the establishment of the council most of which are rather concerning its political than theological considerations. In 2002 through his book, Managing Politics and Islam in Indonesia, Porter argued that it was designed to "co-opt, fragment, and neutralise Islam as an autonomous political force, regulate associational life, and ensure mass turnouts for [the political party] Golkar at election time." Other similar arguments can be seen in Syafiq Hasyim (2011), Martin Van Bruinessen (1996), and Moch. Nur Ichwan (2005) all of which are drawn from its basic statute, describing the Council as a wadah (forum) for consultation among Muslim leaders and scholars, and its threefold tasks; strengthening of religion (understood in the Pancasila way) as a basis of national resilience, the participation of ulama in the development effort, and maintenance of harmonious relations with the other religions.

The orientation and role of this religious institution in the political and social sphere are dynamic in dependence upon its leaders. Under Hamka's leadership (1975-1980), for instance, it put the priority on building external relations with other Muslim organizations, while in Syukri Ghazali's hand (19801984), it turned out to improve the organization's internal management. Unlike the two, Hasan Basri (1985-1998) tried to make the MUI the prime representative of Muslim organizations in Indonesia under whose administration the council took a dominant role in determining the discourse and practice of Islam in Indonesia (Hasyim, 2011, p. 5). Above all, almost all scholars agree that the council had experienced what so-called 'conservative turn' following the collapse of New Order and the rise of democratic light in the political atmosphere of Indonesia.

\section{Islamic Defenders Front (FPI)}

According to General Secretary of Ministry of Home Affairs, Hadi Prabowo, more than four hundred thousand mass organizations exist in Indonesia with far less than its eighth are listed in his administration (Kompas, 2019). Among the big organizations that are most opposed to Ahmadiyya and incessantly condemning its teachings is the Islamic Defenders Front (FPI: Front Pembela Islam). Like MUI, its establishment was very much related to political circumstances. It was founded during political turbulence in 1998 by Misbahul Alam and Habib Rizieq Shihab, the latter of which is henceforth identical with the organization and under whose leadership it plays a crucial role in many attacks against Ahmadiyya and other minority communities. 
Its ideology is taken from Qur'anic edict; al'amru bil-ma'ruf wannahyu'anil-mun'kar (amar ma'ruf and nahi munkar) which is best translated as commanding/enjoining good (right) and fighting/preventing evil (wrong) (Bamualim, 2011, p. 272). After taking it for granted, FPI implements it in practice referring to its own criteria on what is good and what is evil. In pursuit of this goal, they even go further by ignoring the existing law and rights of others. In terms of political administration, the only entity that is in charge of carrying out those two tasks is the state. Nonetheless, FPI feels obliged to take over the state's role in doing so for it is perceived as unable or fail to do so.

Structurally speaking, it consists of two types of membership; Jemaah and Laskar. Jemaah members are those who regularly attend religious sessions held by the organization. They commonly come from a lower-middle-class society thirsted by spiritual experiences and finally attracted by religious activities and preaching by the organization's elites. Laskar is mostly understood as militia or fighters, a vigilant wing of its membership. They are often involved in many violent attacks, not only against minority groups but also against public places deemed as a nest of social ills. Accordingly, they were thugs, homeless, unemployed, and other disadvantaged people who found and viewed FPI as a means to repent and get a better life, both on this planet and in the hereafter (Bamualim, 2011, pp. 271-272). Pairing both with two tasks carried by FPI, it is allegedly known that the first is assigned to do amar ma'ruf while the second for nahi munkar (Petru, 2015, p. 57).

The Civil Association of Victims of the Ahmadiyya Heretical Sect (IMKASA - Ikatan Masyarakat Korban Aliran Sesat Ahmadiyah)

There is no much literature discussing this community as it is neither large in number nor familiar in a name. This group is peculiar to Tasikmalaya region for it is created directly by its local administration to accommodate Ahmadis who decided to leave the community for reasons. However, in its progress, this group is fulfilled by ex-Ahmadis who feel deceived by and even take a stance to strike back theologically against the community. The administrator claims that there have been around 190 Ahmadis who repent and "re-embrace Islam." They do not only grant them religious guidance but also financial aid. This phenomenon of reconversion is seen as an achievement of local government in dealing with Ahmadiyya as a deviant sect.

From Ahmadis perspective, however, the information is deliberately made by the government to prevent other people from accepting and joining Ahmadiyya. The number of members of this association is, in fact, not as huge as the government describes it. According to them, there are only around 13 ex-Ahmadis who leave the community for economical reasons. They are tantalised with an amount of money and various basic needs such as noodles, sugar, and edible oil (Mudzakkir, 2017, p. 69).

\section{Mosque Boards}

Tasikmalaya is well known as an area of 1000 pesantrens (Islamic boarding school) in which mosque serves as one of the obligatory buildings. This is not to mention other non-pesantren both private and public mosques that can be found almost everywhere with very short distances one to each other. By looking at this calculation alone, a great result might be appeared to cover many mosques. They are assembled under three main organizations: BKMM (Badan Koordinasi Majlis Ta'lim Masjid Coordination Board of Masjid's Majelis Ta'lim), DMI (Dewan Masjid Indonesia - Indonesian Mosque Council), and DKM (Dewan Kemakmuran Masjid - Prosperity Council of Mosque).

DMI supervised all existed mosques in Indonesia and aimed to bring the functions of a mosque as a central place of worship, civil society development, and Muslim unity into realisation. Meanwhile, in each mosque, DKM managed a certain single one with commonly three main divisions: 'Idarah (Mosque Management Administration), 'Imarah (Prospering Mosque Activities), and Ri'ayah (Physical Mosque Maintenance). Finally, a good DKM is supposed to establish BKMM to organise its regular agendas. This Board is responsible to activate the mosque through religious discussions and ceremonials. However, this is plausible by considering the character of its citizens who have a very strong religious 
sensitivity for whom mosque thereby is an unshakable symbol for their religious piety, and their strong religiosity is also understandable by dating back at the historical journey of the city.

Those actors by whom Ahmadis are perpetually opposed in such violent ways can be simply divided into three large groups; civil society organizations, mosque boards, and government institutions or apparatuses. They play their distinct role in minoritising Ahmadis in some of which they are somehow engaged in a political interplay. Both the first and the second function as an ideology provider, justifier in favor of, and setting a supportive background for political liminality. This might takes the form of institutional decree, suppression, religious legitimacy, and so on. The ambiguous role of religion in the Indonesian political sphere enables this to happen by conferring those organizations the opportunity to shape their social authority in vying with political institutions (Schäfer, 2015).

Meanwhile, the last is the one responsible for executing and implementing it in practice. Government stakeholders who hold official power to pass legal products through and make policies play this very role. In this sense, a virulent conspiracy between state and non-state actors is smelled out aimed to create a liminal space for the minority in terms of legal and political junctures. The consequence of the liminalisation is unimaginable suggesting that their civil rights are postponed and persecution against them end up with no legal charges. Only at this point, they eventually resemble Agamben's idea of homo sacer.

\section{Conclusions}

To conclude the discussion, rather than repeating the results that have been explored comprehensively, I found it worthier to put some critical notes on the key works referred to in this paper and end it with a suggestion for future research. The liminal and ambiguous characters of Ahmadiyya should not be understood partially for it will end up with nothing but neither a normal perception of two or more communities that hold different faiths and traditions toward each other or breathless laws set on legal display since they meet no implementation. Considering those who do not belong to one's community as 'others' is a psychological product that resulted in consequence of the rise of social media (Mursyidi, 2019) and competition for authority (Schäfer, 2015, pp. 502-503) as this the case for other inter or intra-religious relation everywhere. Therefore, Burhani's first and second aspects sound familiar in our daily interaction with outsiders.

This liminality turned to matter when it extends both politically and constitutionally which is exemplified by the third and fourth aspects and affirmed by Sudibyo's discussion. Their questionable religious status as to whether Islam or not sparks tension in both constitutional rights fulfillment and the political domain. For they are not fully accepted as part of Islam, their civil rights are postponed and sometimes considerably neglected. For their citizenship is unlawfully problematised, they are not protected from unlawful violent acts and the violators are left free without, if any, charge. In this very moment, only the liminalisation reaches its final point in which the minority can be conceptually seen as a liminal community.

Conversely, the liminal product of laws and politics means nothing unless they are manifested through social implementation by a practical sense of minoritisation or marginalisation. The phenomena lately coloring the social dynamic of Indonesians contributed to the reproduction of liminality in political and legal aspects in a way the latter provided legal justifications for the former. The 1965 Blasphemy Law, for instance, is almost found paralytic for those who are allegedly identified blasphemous face no social nuisances during the New Order regime whose political climate leaves no room for social tensions.

Keeping this significant drawback in mind, this is very much worthy to notice that categories in the concept of liminality suggested by both Burhani and Sudibyo should be treated as interwoven to each other for dissociating them will merely reduce either the context or the point toward which it is principally made. In terms of empirical research, the liminal perception of one's community means nothing if followed by political implications that practically put the community in a disadvantageous position as a citizen. In this regard, subsequent researches seeking out that reciprocality is worth waiting. 


\section{References}

Agamben, G. (1998). Homo Sacer: Sovereign Power and Bare Life. Stanford: Stanford University Press.

Ahyar, M. (2015). Ahmadiyah dalam Labirin Syariah dan Nasionalisme Ketuhanan di Indonesia. Mazahib, 14(2), 109-118.

As' ad, M. (2009). Ahmadiyah and the Freedom of Religion in Indonesia. Journal of Indonesian Islam, 3(2), $390-413$.

Bamualim, C. S. (2011). Islamic militancy and resentment against Hadhramis in post-Suharto Indonesia: A case study of Habib Rizieq Syihab and his Islamic Defenders Front. Comparative Studies of South Asia, Africa and the Middle East, 31(2), 267-281.

Berenschot, W., \& Van Klinken, G. (2018). Informality and citizenship: the everyday state in Indonesia. Citizenship Studies, 22(2), 95-111.

Budiwanti, E. (2009). Pluralism collapses: A study of the Jama'ah Ahmadiyah Indonesia and its persecution. In ARI Working Paper Series (No. 117).

Burhani, A. N. (2014). Hating the Ahmadiyya: The place of "heretics" in contemporary Indonesian Muslim society. Contemporary Islam, 8(2), 133-152. https://doi.org/10.1007/s11562-014-0295-x

Connley, A. (2016). Understanding the oppressed: A study of the Ahmadiyah and their strategies for overcoming adversity in contemporary Indonesia. Journal of Current Southeast Asian Affairs, 35(1), 29-58.

Elson, R. E. (2009). Another look at the Jakarta Charter controversy of 1945. Indonesia, (88), 105-130.

Fowler, W. W. (1911). The Original meaning of the word Sacer. Journal of Roman Studies, (1), 57-63.

Guillaume, X. (2014). Regimes of Citizenship. In E. Isin \& P. Nyers (Eds.), Routledge Handbook of Global Citizenship Studies (pp. 150-167). London: Routledge.

Hasyim, S. (2011). The Council of Indonesian Ulama (Majelis Ulama Indonesia, MUI) and Religious Freedom. Irasec's Discussion Papers, 12, 3-26.

Ichwan, M. N. (2005). “Ulamā”, State and Politics: Majelis Ulama Indonesia After Suharto. Islamic Law and Society, $12(1), 45-72$.

Ismail, F. (2004). Islam vis-à-vis Pancasila: political tensions and accommodations in Indonesia, 1945-1995. Jakarta: Mitra Cendekia.

Klinken, G. van, \& Berenschot, W. (2018). Everyday Citizenship in Democratizing Indonesia. In R. W. Hefner (Ed.), Routledge Handbook of Contemporary Indonesia (pp. 151-162). London: Routledge.

Kompas. (2019). Kemendagri Catat Jumlah Ormas Meningkat, Capai 431.465 Organisasi. Retrieved October 20, 2020, from Kompas website: https:/nasional.kompas.com/read/2019/11/25/11151051/kemendagri-catatjumlah-ormas-meningkat-capai-431465-organisasi?page=all

Latif, Y. (2011). Negara Paripurna: Historisitas, Rasionalitas, dan Aktualitas Pancasila. Jakarta: Gramedia Pustaka Utama.

Mariani, N. (2013). Ahmadiyah, conflicts, and violence in contemporary Indonesia. Indonesian Journal of Islam and Muslim Societies, 3(1), 1-30.

Menchik, J. (2016). Islam and Democracy in Indonesia: Tolerance without Liberalism. New York: Cambridge University Press.

Mudzakkir, A. (2011). Minoritisasi Ahmadiyah di Indonesia. Masyarakat Indonesia, 37(2), 1-24.

Mudzakkir, A. (2017). Konservatisme Islam dan Intoleransi Keagamaan di Tasikmalaya. Jurnal Multikultural $\mathcal{E}$ Multireligius, 16(1), 57-74.

Mursyidi, A. F. (2019). Atomized Society: The Role of Women and Social Media in Cultivating Multipolar Outcome of Globalization. Palastren Jurnal Studi Gender, 12(2), 345-366.

Nurdin, A. A., Jamaludin, A. N., Supriatna, E., \& Kustana, K. (2019). The dynamic of religious life: A study of conflict and integration of Ahmadiyah in Garut, Tasikmalaya and Kuningan, West Java. Komunitas: International Journal of Indonesian Society and Culture, 11(1), 63-74.

Petru, T. (2015). The Front Pembela Islam: Well-connected Indonesian Radicals - a Threat or a Spent Force? In T. Petru (Ed.), Graffiti, Converts, and Vigilantes: Islam Outside the Mainstream in Maritime Southeast Asia. Vienna: Caesar Press.

Ropi, I. (2010). Islamism, Government Regulation, and the Ahmadiyah Controversies in Indonesia. Al-Jami'ah: Journal of Islamic Studies, 48(2), 281-320.

Ropi, I. (2017). Religion and regulation in Indonesia. Singapore: Springer.

Schäfer, S. (2015). Renegotiating Indonesian secularism through debates on Ahmadiyya and Shia. Philosophy $\mathcal{E}$ Social Criticism, 41(4-5), 497-508.

Sofianto, K. (2011). Gerakan jamaat Ahmadiyah Indonesia Jawa Barat 1931-2000: Penyebaran ideologi dan respon masyarakat. Fakultas Sain dan Kemanusiaan Universitas Kebangsaan Malaysia.

Sudibyo, A. (2019). Penelantaran Warga Minoritas Dalam Kerangka NKRI: Evaluasi Kritis Atas Penerapan UU 
No.1/PNPS/1965. In F. Sumarni (Ed.), Perjuangan Belum Berakhir: Membela Hak Konstitusional Muslim Ahmadiyah. Malang: Neratja Press.

Valentine, S. R. (2014). Prophecy after the Prophet, albeit lesser prophets? The Ahmadiyya Jama'at in Pakistan. Contemporary Islam, 8(2), 99-113.

van Bruinessen, M. M. (1996). Islamic state or state Islam? Fifty years of state-Islam relations in Indonesia. In I. Wessel (Ed.), Indonesien am Ende des 20 (pp. 19-34). Hamburg: Abera-Verlag.

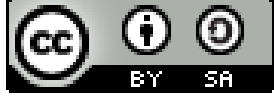

(C) 2020 by the authors. Submitted for possible open access publication under the terms and conditions of the Creative Commons Attribution (CC BY SA) license (https://creativecommons.org/licenses/by-sa/3.0/). 
This page intentionally left blank 